\title{
The murine CC chemokine, 6C-kine, inhibits tumor growth and angiogenesis in a human lung cancer SCID mouse model
}

Received: 15 June 2000 / Accepted: 18 August 2000

\begin{abstract}
The recently described CC chemokine, 6Ckine, is unique in that it contains -six rather than the usual four conserved cysteines typical of this family. Furthermore, murine 6C-kine binds to one of the CXC chemokine receptors CXCR3, in addition to its other known receptor CCR7. We have shown that two other ligands of CXCR3, IP-10 and MIG, are potent inhibitors of tumor growth in severe combined immunodeficiency (SCID) mice. We postulated that murine 6C-kine may also inhibit tumor growth via inhibition of angiogenesis in this model. SCID mice ( $n=6$ per group) inoculated with A549 human lung cancer cells were treated with either 6C-kine (100 ng intra-tumor injection every other day) or control protein for 8 weeks. Tumors from murine 6C-kine-treated mice $\left(288 \pm 26 \mathrm{~mm}^{3}\right)$ were significantly smaller than tumors from control treated mice (788 $\left.\pm 156 \mathrm{~mm}^{3}, P=0.005\right)$. Additionally, murine 6C-kine reduced metastases compared with controls $(0.5 \pm 0.3$ vs $3.0 \pm 1.2$ metastases per animal, $P=0.05)$. Tumor vascularity (as assessed by vessel density counting) was reduced in murine 6C-kine-treated mice
\end{abstract}

D. A. Arenberg · S. R. B. Strom

Department of Internal Medicine,

Division of Pulmonary and Critical Care Medicine,

University of Michigan Medical School,

Ann Arbor, MI 48109-0642, USA

A. Zlotnick

DNAX Research Institute, Palo Alto,

CA 94394-1104, USA

M. D. Burdick · R. M. Strieter

Department of Medicine,

Division of Pulmonary \& Critical Care Medicine,

University of California Los Angeles (UCLA),

Los Angeles, CA 90095-1690, USA

D. A. Arenberg $(\varangle)$

University of Michigan Medical Center,

Division of Pulmonary and Critical Care,

6301 MSRB III, Box 0642, 1150W. Medical Center Drive,

Ann Arbor, MI 48109, USA

e-mail: darenber@umich.edu

Tel.: + 1-734-9362612; Fax: + 1-734-7644556 compared with controls. Murine 6C-kine had no direct effect on proliferation of A549 cells, and there were no differences in the infiltration of leukocyte sub-populations, assessed by flow cytometry, in the treatment groups. Interestingly, human 6C-kine, unlike murine 6Ckine, does not bind CXCR3 and had no anti-tumor effect in the same model. These data suggest that murine $6 \mathrm{C}$ kine has anti-tumor effects independent of its leukocyterecruiting activity. Furthermore, while not confirmatory, these data lend further support to the fact that CXCR3 may be the receptor for angiostatic CXC chemokines.

Key words Cytokine Angiogenesis - Animal models · Tumor

\section{Introduction}

The dependence of tumor growth upon angiogenesis has been the subject of intense research in recent years. It is the balance between angiogenic and angiostatic factors that regulates angiogenesis in any tissue, and studies of tumor associated angiogenesis have yielded many new factors capable of regulating this process. A family of molecules known as chemokines is important in the regulation of angiogenesis [1]. The CXC chemokine family is named after the amino acid sequence describing the first of two highly conserved cysteine amino acid residues, separated by a third non-conserved amino acid. This family can be further divided into those which are angiogenic and those which are angiostatic, based upon the presence (angiogenic) or absence (angiostatic) of a three-amino-acid motif immediately preceding the first conserved cysteine in the primary structure, the glutamic acid-leucine-arginine (ELR) motif. The ELR motif was first found to be important in binding and activation of neutrophils [2]. However, we have shown that the ELR motif is also critical in determining the angiogenic activity of these molecules [3].

We and others have shown that the $\mathrm{CXC}$ chemokines may regulate tumor-derived angiogenic activity in a 
variety of cancers, including lung [1], gastric [4], prostate [5], and CNS [6] tumors, as well as in models of Burkitt's lymphoma [7] and melanoma [8,9]. In this study we report that a member of the $\mathrm{CC}$ chemokine family, known as 6C-kine, has anti-tumor activity that is attributable to its angiostatic property. C-kine has six cysteines rather than the four cysteines that characterize most of the CC chemokine family [10].

6C-kine (also known as secondary lymphoid chemokine-SLC, exodus 2, or CCL21) is important in recruiting activated dendritic cells and T-cells to lymphoid follicles. Although it is classified as a $\mathrm{CC}$ chemokine, murine 6C-kine has been shown to bind to the CXC chemokine receptor, CXCR3 [11]. Interestingly, while murine 6C-kine binds CXCR3, human 6C-kine binds neither human nor murine CXCR3 [12]. Human 6C-kine does bind the other known 6C-kine receptor, CCR7, in both murine and human form [12]. Binding to CXCR3 is a property that murine 6C-kine shares with two of the angiostatic CXC chemokines, interferon-inducible protein 10 (IP-10), and monokine induced by interferon- $\gamma$ (MIG). We hypothesized that, similar to other CXCR3 ligands, murine $6 \mathrm{C}$-kine would have anti-tumor activity in a SCID mouse model of human non-small-cell lung cancer (NSCLC) that is dependent upon angiostatic activity. To test this hypothesis, we used a well-characterized chimeric model of human NSCLC in SCID mice and treated animals with intratumor injections of $6 \mathrm{C}$ kine or vehicle control. SCID mice were employed to isolate the angiostatic effect of $6 \mathrm{C}$-kine from the known immune-mediated anti-tumor effects of 6C-kine as demonstrated by Sharma and colleagues [13]. We found that 6C-kine inhibits tumor growth and metastasis in SCID mice, and that this inhibition is associated with a reduction in tumor vascularity with no change in leukocyte infiltration. This suggests that other ligands of CXCR3, either endogenous or synthetic, might be important therapeutic options for angiostatic therapy of human cancer.

\section{Materials and methods}

\section{Reagents}

Murine and human 6C-kine were a generous gift from R\&D Systems. Antibodies for flow cytometry of tumor digests were as follows: Anti-CD45 (tri-color), FITC-anti-mouse macrophage, phycoerythrin (PE)-anti-mouse NK cells (DX5 clone), and PE-antimouse neutrophil (GR-1) were purchased from CalTag Laboratories (Burlingame, Calif.). Dako (Carpinteria, Calif.) horseradish peroxidase-conjugated antibodies to factor VIII-related antigen were used for immunohistochemical staining of tumor vasculature. Antibodies to rabbit anti-factor VIII-related antigen and pre-immune rabbit-IgG were purchased from Biomeda (Foster City, Calif.). The FITC-conjugated goat anti-rabbit IgG (Pharmingen, San Diego, Calif., USA) was used as a secondary antibody.

\section{Human NSCLC cell lines}

The A549 (adenocarcinoma) cell line (American Type Culture Collection, Rockville, Md.) was maintained in sterile $150 \mathrm{~cm}^{2}$ tissue culture flasks. Cells were cultured and passaged at $37{ }^{\circ} \mathrm{C}$ in $95 \%$ room air $/ 5 \% \mathrm{CO}_{2}$. For proliferation assays, $5 \times 10^{3}$ cells were plated in each well of a 96-well plate and allowed to grow for $24 \mathrm{~h}$, serum starved for $24 \mathrm{~h}$, then treated with varying concentrations of $6 \mathrm{C}$-kine in medium with $1 \%$ serum. After $24 \mathrm{~h}$, cell number was assessed using a non-radioactive cell proliferation assay according to the manufacturer's instructions (CellTiter 96 AQ, Promega, Madison, Wis.). For inoculation into mice, the cells were trypsinized, harvested, washed, and resuspended in serum-free medium at a concentration of $1 \times 10^{7}$ cells $/ \mathrm{ml}$.

\section{Human NSCLC-SCID mouse chimeras}

Four- to six-week-old female CB17-SCID mice (Taconic Farms, Germantown, N.Y.) with serum Ig $<1 \mu \mathrm{g} / \mathrm{ml}$ were injected subcutaneously with human NSCLC cells $\left(1 \times 10^{6}\right.$ cells in $\left.100 \mu \mathrm{l}\right)$ into each flank, and weekly tumor measurements were performed as previously described [14]. Mice received intra-tumor injections of either mouse or human recombinant 6C-kine (100 ng in $20 \mu \mathrm{l}$ of sterile saline every other day) or vehicle [phosphate-buffered saline (PBS) with $0.1 \%$ human serum albumin (HSA)] beginning at the time of tumor inoculation. The lungs were inflated with $4 \%$ paraformaldehyde and fixed in paraffin. An investigator blinded to treatment condition counted visible metastases under an illuminated magnifier $(4 \times)$. Lungs were then embedded in paraffin, sectioned, and H\&E-stained specimens (two from each mouse) were subjected to digital image analysis using NIH Image 1.55 software as previously described [15]. All animals were handled in accordance with the 1985 revised principals of laboratory animal care (NIH publication No. 85-23), as well as protocols established by the University of Michigan Unit for Laboratory Animal Medicine.

Tumor specimens from SCID mice were processed as follows: One portion was fixed in $4 \%$ paraformaldehyde for histologic analysis and immunohistochemistry. Another portion of tumor taken with a standard $6 \mathrm{~mm}$ punch biopsy tool (to equalize the volume of tumor between samples), was minced into single cell suspension using the Dako Medimachine with $50 \mu \mathrm{m}$ blade and filter combination. Cells were then centrifuged at $300 \mathrm{~g}$ for $10 \mathrm{~min}$. Red blood cells were lysed, and cells were washed in PBS and resuspended in fluorescent antibody (FA) buffer [1\% FA buffer (Difco, Detroit, Mich.), $1 \%$ FCS and $0.1 \%$ azide, $1 \times 10^{6}$ cells $\left./ \mathrm{ml}\right]$ and maintained at $4{ }^{\circ} \mathrm{C}$ for the remainder of the staining procedure.

\section{Quantification of infiltrating leukocytes}

One hundred microliters of cells from each tumor was then added to each of eight wells. Cells were blocked with Fc-block (Pharmingen) for $10 \mathrm{~min}$ at $4{ }^{\circ} \mathrm{C}$, then labeled with anti-mouse leukocyte antibody (CD45-tricolor) or isotype control for $30 \mathrm{~min}$ at $4{ }^{\circ} \mathrm{C}$. Cells were washed in FA buffer, then a second antibody was added for $30 \mathrm{~min}$ at $4{ }^{\circ} \mathrm{C}$, one each of the following for each tumor specimen: FITC-conjugated Mac-1 (for macrophages) or isotype control, PE-conjugated DX5 antibody (for NK cells) or isotype control, FITC-conjugated anti-GR-1 (for neutrophils) or isotype control. One unstained specimen for each tumor was used for setting gates for the forward and side scatter characteristics. FACS analysis was then employed to determine the degree and type of leukocyte infiltration.

Macrophages were localized and quantitated in paraffinembedded A549 tumor specimens with 1:1,000 rabbit anti-murine macrophage antibody (CalTag) from mice treated with either 6Ckine or control using our previously described method [16, 17]. Fast Red (BioGenex, San Ramon, Calif.) reagent was used for chromogenic localization of murine macrophages, and sections were counter-stained with Mayer's hematoxylin. Tumor sections were then examined under $400 \times$ magnification and cells counted. A total of four fields per tumor section and six tumors per treatment group were counted. Results were expressed as the number of macrophages per high-power field (hpf; 200x) 
Quantitation of vessel density

For FACS quantification of tumor vascularity, an additional $100 \mu \mathrm{l}$ tumor cells (from the tumor minced at the time of sacrifice) was labeled with rabbit anti-factor VIII-related antigen antibodies to recognize tumor-associated endothelial cells. Pre-immune rabbit $\mathrm{IgG}$ was used as a control. FITC-conjugated goat anti-rabbit IgG was used as a secondary antibody to detect cells expressing factor VIII-related antigen. Tumor vasculature was expressed as the percentage of cells from the tumor that were positive for factor VIII-related antigen. Quantitation of histologic vessel density was performed on paraffin-embedded specimens of tumors from mice treated with either 6C-kine or control, and stained with antibody to factor VIII-related antigen conjugated to horseradish peroxidase (Dako) using our previously described method [14]. Specimen identity was undisclosed and sections scanned at low magnification $(40 \times)$ to identify vascular "hot spots". Areas of greatest vessel density were then examined under higher magnification $(200 \times)$ and counted. Any distinct area of positive staining for factor VIIIrelated antigen was counted as a single vessel. Two tumor sections per animal were stained, and a single "hot-spot" per section was counted. Results were expressed as the number of vessels per hpf $(200 \times)$.

\section{Statistical analysis}

The animal studies involved a minimum of 12 human NSCLC tumors or six SCID mice for each treatment group. Data were evaluated by Student's $t$-test or by the Mann-Whitney test for non-normally distributed data (e.g., size of metastases), and were considered significant if $P$ values were less than 0.05 . Results are presented as means \pm SEM. Data were analyzed on a Macintosh 8600 computer using the Statview 4.5 statistical software package (Abacus Concepts, Berkeley, Calif., USA).

\section{Results}

Murine 6C-kine inhibits tumor growth

The SCID mice were injected with $1 \times 10^{6}$ A549 cells in the subcutis on each flank. One group $(n=6)$ of mice received $100 \mathrm{ng}$ murine 6C-kine (murine 6C-kine) injected into the tumor three times weekly. A second group received vehicle as control (0.1\% HSA in PBS). The dose and timing chosen were based on our previously published experience using IP-10 in this animal model [15]. Tumors from m6C-kine-treated mice $\left(288 \pm 26 \mathrm{~mm}^{3}\right)$ were $63 \%$ smaller than tumors from control-treated mice $\left(784 \pm 156 \mathrm{~mm}^{3}, \quad P=0.005\right.$; Fig. 1). Additionally, metastases were significantly reduced in m6C-kine-treated mice $(0.5 \pm 0.3$ metastases per animal) compared with control-treated mice $(3.0 \pm 1.2$ metastases per animal, $P=0.05$; Fig. 2$)$.

Leukocyte infiltration is not altered by treatment with m6C-kine

As a chemokine, 6C-kine may attract leukocytes to the tumor, which could contribute to anti-tumor activity. While these SCID mice do not have T- or B-cell function, m6C-kine might also reduce tumor growth by attracting tumoricidal macrophages or NK cells to the

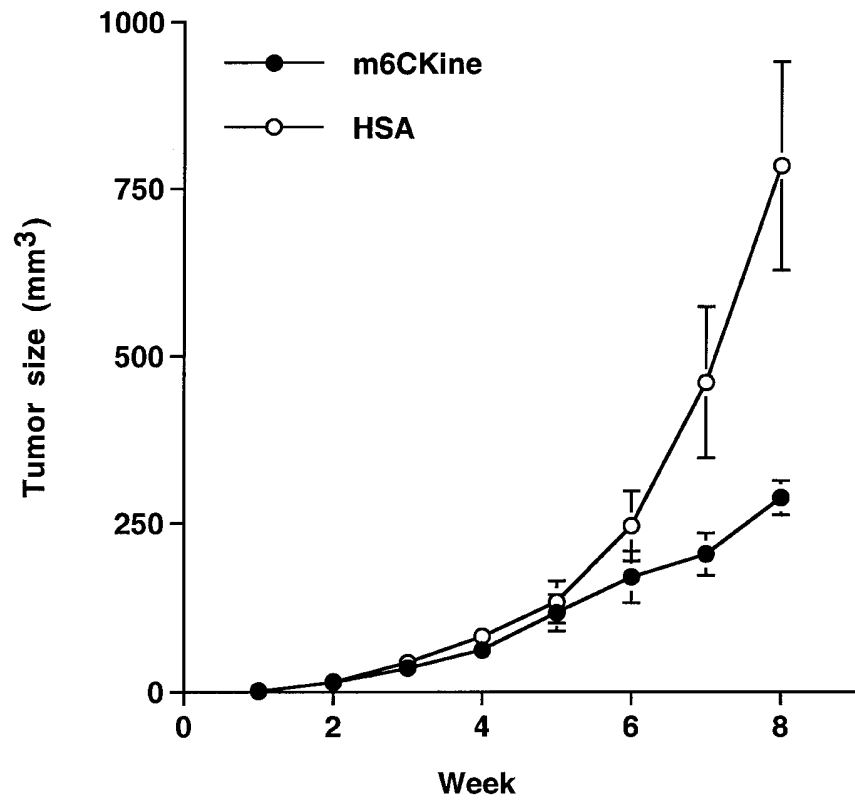

Fig. 1 Tumor size in A549 tumor-bearing SCID mice treated with m6C-kine (100 ng every other day: $288 \pm 26 \mathrm{~mm}^{3}$ at 8 weeks) compared with vehicle control (PBS with $0.1 \%$ HSA: $784 \pm 156 \mathrm{~mm}^{3}$ at 8 weeks; $P=0.005$ )

tumor. In order to investigate this possibility, we performed FACS analysis to quantify the degree of tumor infiltration by sub-populations of leukocytes in m6Ckine- compared with control-treated mice. Tumor digests from m6C-kine-treated mice, as compared to control-treated mice, revealed no significant differences in the degree of infiltration of macrophages (Mac-1), NK cells (DX5), or neutrophils (GR-1; Table 1). As a further confirmation of this finding, we quantified macrophage infiltration in histologic sections of A549 tumors from m6C-kine- and control-treated mice. The number of macrophages per hpf $(400 \times)$ was similar in m6C-kine-treated $(3.2 \pm 0.7)$ and control-treated groups $(3.8 \pm 0.5 ; P=0.5)$.

Vascularity of A549 tumors is reduced in m6C-kine-treated mice

As demonstrated by Soto and colleagues [11], m6C-kine has angiostatic activity. In order to determine whether the reduction in tumor growth in m6C-kine-treated mice was due to inhibition of angiogenesis, we performed FACS analysis on tumor digests to quantify the percentage of cells expressing factor VIII-related antigen. Tumors from mice receiving m6C-kine had a reduced percentage of endothelial cells as determined by FACS analysis $(4.4 \pm 0.6$ vs $6.5 \pm 0.4 \%, P=0.005$; Table 2$)$. We further confirmed this by performing immunohistochemical staining of vessels using antibodies to factor VIII-related antigen on paraffin embedded tumor sections from m6C-kine- and control-treated mice. Vessel density was determined in vascular "hot-spots" scanned 

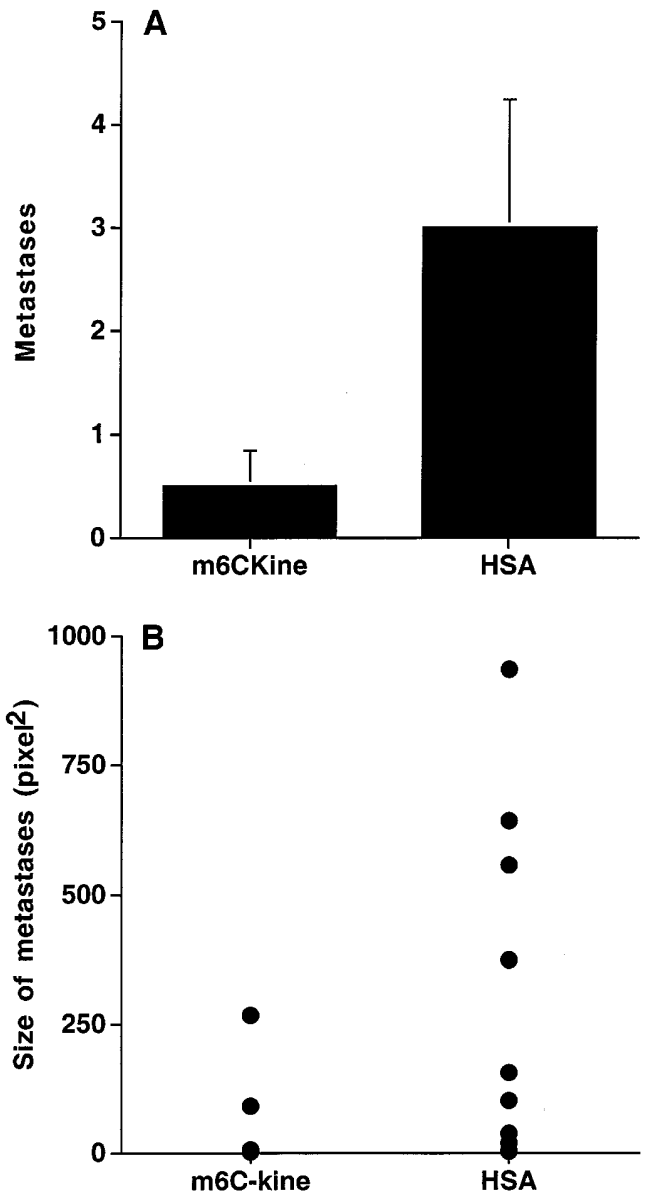

Fig. 2 A Number of grossly visible lung metastases in A549 tumorbearing SCID mice treated with $100 \mathrm{ng}$ of 6C-kine 3 days per week or HSA $(0.1 \%$ HSA vehicle control: $0.5 \pm 0.3$ vs $3.0 \pm 1.2$ metastases per animal, $P=0.05$ ). B Sizes (in square pixels at $40 \times$ ) of microscopically detected lung metastases determined by image analysis $(P=0.05$ for the comparison between groups, MannWhitney U-test)

Table 1 FACS analysis of infiltrating leukocyte sub-populations in A549 tumors from 6C-kine- and control-treated mice. No differences were noted in the degree of leukocyte infiltration (each data point represents an average of data from six mice). Macrophages were also counted by immunohistochemistry in four $400 \times$ high-power fields $(h p f)$ per tumor; $P=0.5, n=6$ tumor sections per treatment group, one per mouse

\begin{tabular}{lcr}
\hline Cell population (marker) & \multicolumn{1}{c}{ 6C-kine } & \multicolumn{1}{c}{ Control } \\
\hline Macrophage (Mac-1) & $8.0 \pm 2.0 \%$ & $9.4 \pm 1.6 \%$ \\
Neutrophil (GR-1) & $6.5 \pm 2.4 \%$ & $6.7 \pm 1.4 \%$ \\
NK cell (DX5) & $12.7 \pm 2.9 \%$ & $15.4 \pm 1.2 \%$ \\
Macrophages/hpf & $3.2 \pm 0.7$ & $3.8 \pm 0.5$ \\
$\quad$ (histology) & & \\
\hline
\end{tabular}

at low magnification $(40 \times)$, counting under a high power field $(200 \times)$. Vessel density was significantly lower in m6C-kine-treated mice $(6.8 \pm 0.9$ vessels $/ \mathrm{hpf})$ than in control mice $(11.4 \pm 0.9$ vessels $/ \mathrm{hpf}, P=0.001$; Table 2).
Table 2 Percentage of endothelial cells determined by FACS analysis for factor VIII-related antigen, and vessel density as determined by factor VIII-related antigen immunohistochemistry. Vascularity was significantly reduced in 6C-kine-treated mice compared with control mice

\begin{tabular}{llr}
\hline Treatment group & 6C-kine & \multicolumn{1}{c}{ Control } \\
\hline $\begin{array}{l}\text { \% Factor VIII-related } \\
\text { antigen }(+) \text { cells by FACS }\end{array}$ & $4.4 \pm 0.6^{*}$ & $6.5 \pm 0.4$ \\
$\begin{array}{l}\text { Vessels } / 200 \times \text { field by } \\
\text { immunochemistry }\end{array}$ & $6.8 \pm 0.9^{* *}$ & $11.4 \pm 0.9$ \\
\hline
\end{tabular}

$* P=0.005 ; * * P=0.001$

m6C-kine does not affect proliferation of NSCLC cells

In order to exclude the possibility that the reduction in tumor growth seen in mice treated with 6C-kine was due to a direct anti-proliferative effect of m6C-kine upon A549 cells, we performed proliferation assays in vitro in the presence of varying doses of m6C-kine. Proliferation was assessed using a non-radioactive proliferation assay. A549 cell proliferation was not reduced in the presence of any concentration of m6C-kine from 1 to $100 \mathrm{ng} / \mathrm{ml}$ (approximately $70 \mathrm{pM}$ to $7 \mathrm{nM}$; Fig. 3).

Human 6C-kine (h6C-kine) does not inhibit tumor growth

While m6C-kine has been found to bind CXCR3, human 6C-kine does not share that property $[11,12]$. We tested h6C-kine in the same animal model to determine whether this lack of CXCR3 binding would be associated with a lack of angiostatic activity (and therefore a lack of anti-tumor activity in SCID mice). In contrast to m6C-kine, treatment of A549 tumor-bearing SCID mice with h6C-kine had no effect on tumor growth compared

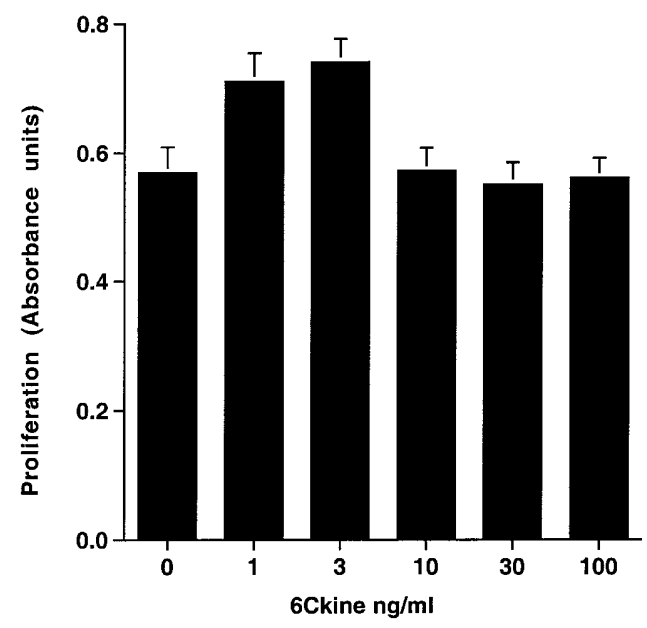

Fig. 3 A549 cell proliferation at $24 \mathrm{~h}$ in vitro in the presence of $6 \mathrm{C}$ kine varying from 1 to $100 \mathrm{ng} / \mathrm{ml}$ (approximately $70 \mathrm{pM}$ to $7 \mathrm{nM}$ ) using a non-radioactive proliferation assay. Data represent an average of three separate experiments 
with control-treated mice $(931.7 \pm 222$ and $805.1 \pm 112 \mathrm{~mm}^{3}$ respectively, $P=0.6$; Fig. 4). Metastases were not reduced in h6C-kine-treated mice compared with controls $(2.7 \pm 1.0$ vs $3.2 \pm 1.0$ metastases per animal, $P=0.7)$.

\section{Discussion}

This study demonstrates anti-tumor activity of m6C-kine in a T- and B-cell-independent model. Recently, Sharma and co-workers used a syngeneic mouse model of lung cancer to demonstrate that $6 \mathrm{C}$-kine has potent T-celldependent anti-tumor activity [13]. These authors also demonstrated the development of protective immunity after re-challenge with tumor cells, as well as adoptive transfer of tumor immunity to naïve animals with T-cells from mice "cured" of their tumors. In contrast to our current findings, Sharma and colleagues found that $6 \mathrm{C}$ kine did not inhibit tumor growth of the LLC cell line in SCID mice. A possible explanation for the discrepancy would be the difference in the growth rates of the two different cell lines used. It is possible that the angiostatic activity of 6C-kine is more effective in slower growing tumors. The LLC cell line used by Sharma et al. grows more rapidly than the A549 cell line. Interestingly, despite the lack of evidence for angiostatic activity in the Sharma study, the authors found that tumors from mice treated with 6C-kine also had a greater frequency of cells expressing interferon- $\gamma$ [13]. Interferon- $\gamma$ by itself can promote an angiostatic environment by inducing the angiostatic factors IP-10 and MIG, and suppress the expression of angiogenic CXC chemokines [18]. Indeed, the measurement of tumor-associated cytokine levels in their study demonstrated an increase in the levels of IP-10 and MIG, as well as a decrease in the levels of VEGF from tumors of mice treated with m6C-kine. Our data using a SCID mouse model suggest that m6C-kine also

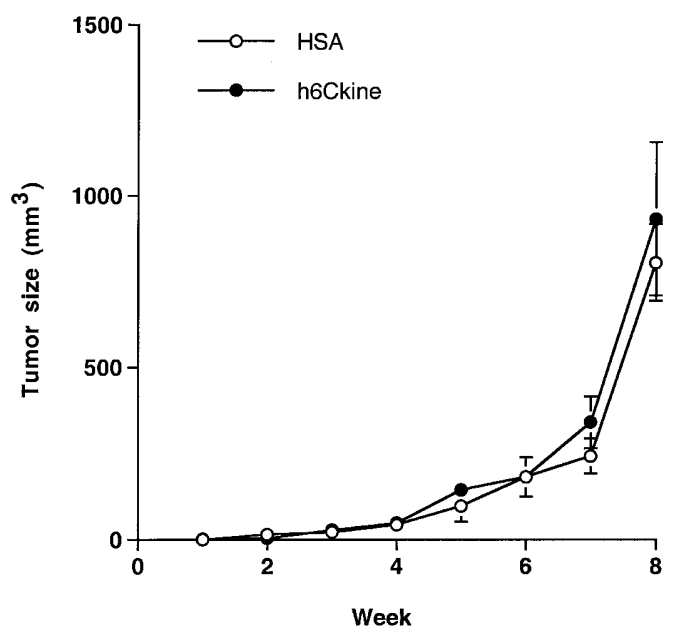

Fig. 4 Tumor size in A549 tumor-bearing SCID mice treated with human 6C-kine $\left(931.7 \pm 222 \mathrm{~mm}^{3}\right.$ at 8 weeks) compared with control (HSA. $805.1 \pm 112 \mathrm{~mm}^{3}$ at 8 weeks. $P=0.6$ ) provides anti-tumor activity that is due to inhibition of angiogenesis. While 6C-kine has been demonstrated to have direct angiostatic activity [11], the findings of Sharma and colleagues, combined with those in the present study, suggest that some indirect angiostatic activity may be relevant to 6C-kine's anti-tumor activity as well.

The significance of our findings is twofold. First, the ability of a single molecule to inhibit angiogenesis [11] and attract lymphocytes [10,19] makes it an attractive candidate as a therapeutic agent. Second, the implications of our findings support the notion that CXCR3 may be another important therapeutic target for antiangiogenic therapy.

CXCR3 is a receptor for two CXC chemokine ligands IP-10, and MIG. We have previously shown that members of the CXC chemokine family are important regulators of angiogenesis. We have found IP-10 and MIG, two angiostatic CXC chemokines, are potent endogenous angiostatic factors in non-small cell lung cancer (NSCLC) [15, 20]. IP-10 and MIG also share the property of being interferon-inducible chemokines, and other investigators have demonstrated that these two chemokines may be responsible for the anti-tumor activity of interleukin-12 [21-23]. While CXCR3 is a receptor for both of these chemokines, no studies to date have demonstrated that it is the receptor that mediates the angiostatic activity of IP-10 and MIG. Soto and colleagues cloned murine CXCR3, and in screening a panel of chemokines for additional ligands found that m6C-kine was able to induce calcium flux in CXCR3-transfected $\mathrm{CHO}$ cells [11]. They also found that m6C-kine inhibited angiogenesis in the rat corneal micropocket assay [11]. The finding that m6C-kine inhibits angiogenesis, while not definitive evidence, supports the notion that CXCR3 mediates the angiostatic effects of these molecules. In further support of this is our finding that human 6C-kine, which does not bind to murine CXCR3 [12], but does bind to the other known murine receptor for m6C-kine, CCR7 (unpublished observations), does not inhibit angiogenesis or tumor growth in our model. It is important to note that the lack of anti-tumor activity of human 6C-kine in SCID mice does not preclude its use as an anti-tumor agent in humans, given its ability to attract activated dendritic cells and T-cells through CCR7.

It is also interesting to note that, similar to IP-10 [15], administration of m6C-kine directly into the tumor inhibits distant metastases. It is unlikely that the quantity of m6C-kine administered (100 ng every other day), reaches sufficient systemic levels to have a direct effect on distant metastases. Rather, we propose that this is an indirect effect on metastases by inhibiting tumor angiogenesis. One hallmark of angiogenesis is increased permeability of the vessel wall [24], a factor likely to facilitate metastases [25]. Inhibition of angiogenesis will probably also result in reduced access to the vasculature by tumor cells.

In summary, we have confirmed the anti-tumor efficacy of m6C-kine, a CC chemokine with angiostatic 
properties. The presence of this anti-tumor activity in a SCID mouse model demonstrates that it is T- and B-cell independent. While the mechanism for the angiostatic activity of m6C-kine awaits further studies, it is attractive to postulate that CXCR3 is the mediator of this activity since this receptor also binds other angiostatic chemokines. Our findings suggest that other agonists of CXCR3 should be sought for their potential angiostatic activity.

Acknowledgements Grant support: This work was supported, in part, by NIH grants CA72543 (D.A.A.), P50HL46487 and P50HL60289 (R.M.S.) and by an American Lung Association research grant RG-065-N (D.A.A.). Dr. Arenberg is a Sidney Kimmel Foundation Scholar. DNAX Research Institute is supported by Schering-Plough Corporation.

\section{References}

1. Arenberg DA, Polverini PJ, Kunkel SL, Shanafelt A, Hesselgesser J, Horuk R, Strieter RM (1997) The role of CXC chemokines in the regulation of angiogenesis in non-small cell lung cancer. J Leukoc Biol 62: 554

2. Hebert CA, Vitangcol RV, Baker JB (1991) Scanning mutagenesis of interleukin- 8 identifies a cluster of residues required for receptor binding. J Biol Chem 266: 18989

3. Strieter RM, Polverini PJ, Kunkel SL, Arenberg DA, Burdick MD, Kasper J, Dzuiba J, Van Damme J, Walz A, Marriott D, Chan S, Roczniak S, Shanafelt A (1995) The functional role of the ELR motif in CXC chemokine-mediated angiogenesis. J Biol Chem 270: 27348

4. Kitadai Y, Haruma K, Sumii K, Yamamoto S, Ue T, Yokozaki H, Yasui W, Ohmoto Y, Kajiyama G, Fidler IJ, Tahara E (1998) Expression of interleukin-8 correlates with vascularity in human gastric carcinomas. Am J Pathol 152: 93

5. Moore BB, Arenberg DA, Stoy K, Morgan T, Addison CL, Morris, SB, Glass M, Wilke C, Xue YY, Sitterding S, Kunkel SL, Burdick MD, Strieter RM (1999) Distinct CXC chemokines mediate tumorigenicity of prostate cancer cells. Am J Pathol 154: 1503

6. Desbaillets I, Diserens AC, de Tribolet N, Hamou MF, Van Meir EG (1999) Regulation of interleukin-8 expression by reduced oxygen pressure in human glioblastoma. Oncogene 18: 1447

7. Sgadari C, Farber JM, Angiolillo AL, Liao F, Teruya-Feldstein J, Burd PR, Yao L, Gupta G, Kanegane C, Tosato G (1997) Mig, the monokine induced by interferon-gamma, promotes tumor necrosis in vivo. Blood 89: 2635

8. Luan J, Shattuck-Brandt R, Haghnegahdar H, Owen JD, Strieter R, Burdick M, Nirodi C, Beauchamp D, Johnson KN, Richmond A (1997) Mechanism and biological significance of constitutive expression of MGSA/GRO chemokines in malignant melanoma tumor progression. J Leukoc Biol 62: 588

9. Owen JD, Strieter R, Burdick M, Haghnegahdar H, Nanney L, Shattuck-Brandt R, Richmond A (1997) Enhanced tumorforming capacity for immortalized melanocytes expressing melanoma growth stimulatory activity/growth-regulated cytokine beta and gamma proteins. Int J Cancer 73: 94

10. Hedrick JA, Zlotnik A (1997) Identification and characterization of a novel beta chemokine containing six conserved cysteines. J Immunol 159: 1589
11. Soto H, Wang W, Strieter RM, Copeland NG, Gilbert DJ, Jenkins NA, Hedrick J, Zlotnik A (1998) The CC chemokine 6Ckine binds the CXC chemokine receptor CXCR3. Proc Natl Acad Sci USA 95: 8205

12. Jenh $\mathrm{CH}$, Cox MA, Kaminski H, Zhang M, Byrnes H, Fine J, Lundell D, Chou CC, Narula SK, Zavodny PJ (1999) Cutting edge: species specificity of the CC chemokine 6Ckine signaling through the CXC chemokine receptor CXCR3: human 6Ckine is not a ligand for the human or mouse CXCR3 receptors. J Immunol 162: 3765

13. Sharma S, Stolina M, Luo J, Strieter RM, Burdick M, Zhu LX, Batra RK, Dubinett SM (2000) Secondary lymphoid tissue chemokine mediates $\mathrm{T}$ cell-dependent antitumor responses in vivo. J Immunol 164: 4558

14. Arenberg DA, Keane MP, DiGiovine B, Kunkel SL, Morris SB, Xue YY, Burdick MD, Glass MC, Iannettoni MD, Strieter RM (1998) Epithelial-neutrophil activating peptide (ENA-78) is an important angiogenic factor in non-small cell lung cancer. J Clin Invest 102: 465

15. Arenberg DA, Kunkel SL, Polverini PJ, Morris SB, Burdick MD, Glass M, Taub, DT, Iannetoni MD, Whyte RI, Strieter RM (1996) Interferon- $\gamma$-inducible protein 10 (IP-10) is an angiostatic factor that inhibits human non-small cell lung cancer (NSCLC) tumorigenesis and spontaneous metastases. J Exp Med 184: 981

16. Rolfe MW, Kunkel SL, Standiford TJ, Chensue SW, Allen RM, Evanoff HL, Phan SH, Strieter RM (1991) Pulmonary fibroblast expression of interleukin-8: a model for alveolar macrophage-derived cytokine networking. Am J Respir Cell Mol Biol 5: 493

17. Smith DR, Kunkel SL, Standiford TJ, Chensue SW, Rolfe MW, Orringer MB, Whyte RI, Burdick MD, Danforth JM, Gilbert AR, Strieter RM (1993) The production of Interleukin1 receptor antagonist by human bronchogenic carcinoma. Am J Pathol 143: 794

18. Schnyder-Candrian S, Strieter RM, Kunkel SL, A AW (1995) Interferon-a and interferon-g downregulate the production of interleukin-8 and ENA-78 in human monocytes. J Leukoc Biol 57: 929

19. Kellermann SA, Hudak S, Oldham ER, Liu YJ, McEvoy LM (1999) The CC chemokine receptor-7 ligands 6Ckine and macrophage inflammatory protein-3 beta are potent chemoattractants for in vitro- and in vivo-derived dendritic cells. J Immunol 162: 3859

20. Addison C, Arenberg D, Morris S, Xue Y, Burdick M, Mulligan M, Iannetoni M, Strieter R (2000) The CXC chemokine, monokine induced by interferon gamma (MIG), inhibits nonsmall cell lung cancer (NSCLC) tumor growth and metastasis. Hum Gene Ther 11: 247

21. Sgadari C, Angiolillo AL, Tosato G (1996) Inhibition of angiogenesis by interleukin-12 is mediated by the interferoninducible protein 10. Blood 87: 3877

22. Angiolillo AL, Sgadari C, Tosato G (1996) A role for the interferon-inducible protein 10 in inhibition of angiogenesis by interleukin-12. Ann N Y Acad Sci 795: 158

23. Kanegane C, Sgadari C, Kanegane H, Teruya-Feldstein J, Yao L, Gupta G, Farber JM, Liao F, Liu L, Tosato G (1998) Contribution of the CXC chemokines IP-10 and Mig to the antitumor effects of IL-12. J Leukoc Biol 64: 384

24. Folkman J (1993) Tumor angiogenesis. In: Holland JF, Frei E III, Bast RC Jr, Kufe DW, Morton DL, Weischelbaum RR (eds) Cancer medicine, vol 1. Lea \& Febiger, Philadelphia, p 153

25. Fidler IJ (1990) Critical factors in the biology of human cancer metastasis: Twenty-Eighth G.H.A. Clowes Memorial Award Lecture. Cancer Research 50: 6130
Note added in proof Since the submission of this manuscript, Vicari and co-workers have reported that m6C-kine can exert anti-tumor effects through both immunologic and angiostatic mechanisms. (J Immunol (2000) 165: 1992) 